\title{
Potential for timing high-energy marine inundation events in the recent geological past through age-dating of reef boulders in Fiji
}

\author{
James P Terry ${ }^{1 *}$ and Samuel Etienne $e^{2,3}$
}

\begin{abstract}
Transported coastal boulders have increasingly come to represent a valuable element of investigations within the broader framework of multi-proxy approaches applied to coastal hazard studies. Through a case study on Taveuni Island in Fiji, this paper outlines some approaches and hindrances to effective timing of prehistorical high-energy marine inundation events (storms and tsunamis) on tropical coastlines from the evidence of reef-platform carbonate boulders. Various sources of errors are outlined that investigators must consider when attempting to use carbonate boulder ages as a surrogate for timing past events. On Taveuni, uranium : thorium dates with a high level of precision (1-7 years) suggest that major inundation events have a return period of approximately 40-45 years since 1650 AD. Of particular importance, considerably different age dates are provided by coral samples sourced from the top and bottom (i.e. opposite faces) of individual boulders, so highlighting interpretation biases that must be avoided.
\end{abstract}

Keywords: Reef boulders; Tropical cyclones; Tsunamis; Marine inundation; Coral dating; Coastal geomorphology

\section{Background}

Boulder analysis for interpreting coastal hazards

In recent years the study of high-energy marine inundation (HEMI) events on tropical coastlines has become increasingly popular as researchers try to develop a better understanding of the frequency of coastal hazards [1,2]. In part, this is the result of both public and scientific attention being brought into sharper focus by tragic events such as the 2004 Indian Ocean and 2011 Tōhoku-oki tsunamis, as well as the annual litany of severe tropical cyclones and typhoons. A growing field of interest for geomorphologists is the study of coarse clastic sediments (i.e. boulders) on tropical coastlines [3]. Boulder presence on coasts is increasingly cited as a signature for past high-energy marine inundation (HEMI) events, such as driven by tsunamis (e.g. [4-6]) or powerful storm waves (e.g. [7-10]). If interpreted carefully, the geological evidence of coastal boulder deposits is commonly able to shed light on the characteristics of unrecorded events in the past. This is valuable because it helps in the task

\footnotetext{
* Correspondence: James.Terry@zu.ac.ae

${ }^{1}$ College of Sustainability Sciences and Humanities, Zayed University, Dubai, United Arab Emirates

Full list of author information is available at the end of the article
}

of recognizing coastal vulnerability to hazards in many locations.

Across a range of environmental settings worldwide, boulders are often highly visible features on shorelines (e.g. [11-13]), especially in tropical regimes where coral reefs are present [14]. The relatively large size of boulders is their key characteristic as it means that they are not so easily remobilized in the quiescent periods between major HEMI events as finer sands and gravels. Boulder-sized clasts sometimes exhibit greater permanence over finer sediment [15]. Moreover, in terms of their access for investigation, conspicuous boulders resting on exposed reef platforms have advantages for identification and sampling over fine deposits that are more difficult to investigate if laid down in coastal lagoons, buried within mangroves or obscured by shoreline vegetation.

Although there are many possible mechanisms for the production of coastal boulders, on tropical coastlines where fringing coral reefs exist, these provide both the primary source of carbonate boulders and a suitable flat platform near sea level, often with high surface roughness, encouraging boulder accumulation and preservation (Figure 1). Such carbonate clasts torn off the seaward edges of living coral reefs by powerful storm or tsunami waves have been 


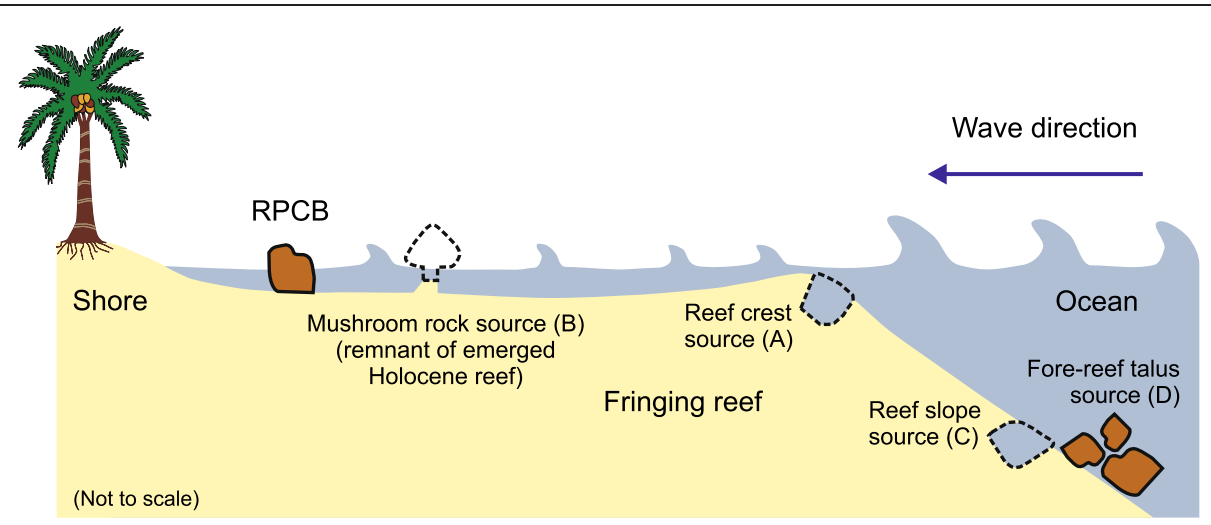

Figure 1 Four possible origins for reef-platform carbonate boulders (RPCBs) deposited on a tropical coastline with adjacent fringing reefs. Living coral framework is the usual source of RPCBs, produced when a fragment of the reef crest is quarried, transported and then deposited on the reef platform by high-energy wave action. If a RPCB is quarried from the reef crest (A) then dating of fossil corals is useful. Dating of RPBCs that are sourced from Holocene reef remnants (B), older parts of the reef structure (C), submarine talus (D), or reworked pre-existing boulders on the reef (not shown), will provide spurious ages. This is because coral mortality predates by an unknown period of time the HEMl events that transported them to their current reef-top position.

referred to as 'reef-platform carbonate boulders' or RPCBs [16], and are the focus of attention in this paper.

\section{Timing of past events}

For many low-lying coastal areas, historical records of past HEMI events from which valuable lessons may be learned are scarce [17]. Even where records are documented, their relatively short duration is often an obstacle that restricts their usefulness for meaningful vulnerability assessment. Notwithstanding the potential offered by coastal boulder studies for illuminating key features of significant but unrecorded HEMI events, a number of challenges still remain.

Although it may be possible using coastal boulder analysis to estimate the magnitude of past HEMI events, arguably the most fundamental goal is to decipher the approximate timing and frequency of those events. Another goal is determining whether storms or tsunamis were responsible. Knowing when or how often those events occurred throughout the prehistorical period is critical for gaining insight on the return periods of highmagnitudes events, and ultimately in preparing for the impacts of possible future potentially catastrophic inundation hazards. Age-dating and frequency analysis of past unrecorded events are therefore desirable pursuits. Coral reef coastlines in tropical environments present an advantage, as the carbonate make up of RPCBs offers good potential for age-dating that may be impossible with other types of boulder lithology. That being said, however, establishing direct links between the ages of carbonate boulders and the actual timing of their emplacement on coasts also brings its own set of problems. The aim of this paper is to present a brief case study on Taveuni Island in Fiji, suggesting how some of the issues can be overcome through selective sampling and dating.

\section{Methods}

U:Th age-dating of carbonate boulders

For estimating the approximate age of past HEMI events from the analysis of coastal boulders, one option is to compare time series of high-resolution satellite images or aerial photographs (e.g. $[12,18])$. For obvious reasons this method is confined to the relatively modern era of remote image acquisition. With regard to prehistorical events, boulder age-dating is a more plausible alternative. With RPCBs, it is possible to date the fossil corals that make up the carbonate structure of the boulder itself. For this method to be applicable, it is necessary to assume that mortality of the corals occurred as a direct consequence of the HEMI event that quarried the clast out of the living reef to produce the RPCB (see Discussion on hindrances to timing of past HEMI events section). If this assumption is correct, then the date of coral mortality is taken to represent the timing of the HEMI event [19].

Radiocarbon dating is one possibility to establish the age of the fossil corals in a carbonate boulder (e.g. [11]), but calibration difficulties and errors in radiocarbon age mean that this dating method is less suitable for relatively recent boulders formed within about the last three or four centuries. Uranium-series dating provides a suitable alternative $[20,21]$. The uranium-series technique measures the ratio of ${ }^{238} \mathrm{U}:{ }^{234} \mathrm{U}:{ }^{230} \mathrm{Th}$ (uranium-238 : uranium-234 : thorium-230) to obtain the age of a carbonate sample. During the growth of corals, small quantities of uranium are taken up from sea water and incorporated into the $\mathrm{CaCO}_{3}$ mineral, while thorium is not present as it is absent in sea water [22]. Knowing the half-lives of ${ }^{234} \mathrm{U}$ and ${ }^{230} \mathrm{Th}(244,600$ and 75,380 years respectively), the age of dead coral can be determined if the initial ${ }^{234} \mathrm{U}:{ }^{238} \mathrm{U}$ ratio is established from living coral. Using the modern TIMS (Thermal Ionization Mass Spectrometry) 
U-series technique, for fossil corals younger than 1000 years old, dating is sometimes possible with extraordinary precision to within $1-5$ years (or $1-2 \%$ uncertainty) $[5,19-21,23]$. However, in spite of this precision for coral ages, the accuracy of results is more debatable, i.e. how closely coral ages represent the actual timing of the HEMI events that produced the carbonate boulders is influenced by a number of factors, as discussed in Discussion on hindrances to timing of past HEMI events section.

\section{Case study: Taveuni Island, Fiji \\ Study sites}

Taveuni Island $\left(16^{\circ} 49^{\prime} \mathrm{S} 179^{\circ} 58^{\prime} \mathrm{E}\right)$ is the third largest island in the Pacific nation of Fiji, and lies to the north of the main archipelago. The greater proportion of Taveuni's coastline is pristine and undisturbed. Coral reefs fringe the northern and eastern central coasts, extending seaward from the shoreline as broad platforms that reach between 100-500 $\mathrm{m}$ in width (Figure 2).

In mid-March 2010, category-4 intensity Tropical Cyclone Tomas tracked within $30 \mathrm{~km}$ of the eastern coast of Taveuni. This was the severest cyclone to strike the island in living memory. To examine the geomorphic changes brought about on Taveuni's coastlines, a campaign of field investigation was carried out four months post-event, as described in Etienne and Terry [24]. Extensive boulder fields comprising many hundreds of individual RPCBs scattered across the reef platforms were discovered. Most possessed block and slab morphologies and appeared to be fragments of reef-edge pavement rather than individual rounded coral heads. According to the denuded state of most RPCBs, and the opinions of local guides, it was established that up to $80 \%$ of the total number examined predated the 2010 TC Tomas event. These pre-existing RPCBs thus signify the occurrence of earlier HEMI events, probably of significant antiquity. Of particular interest was that many old RPCBs were considerably more sizeable than those produced by TC Tomas: the biggest exceeding $40 \mathrm{~m}^{3}$ while 16 others were greater than the largest new clast (i.e. $>5 \mathrm{~m}^{3}$ ). No surficial evidence of recent transport such as grooves, crush marks or scars could be identified. The conclusion was reached that waves driven onshore by the unknown HEMI events had greater energy than those generated by TC Tomas [24].

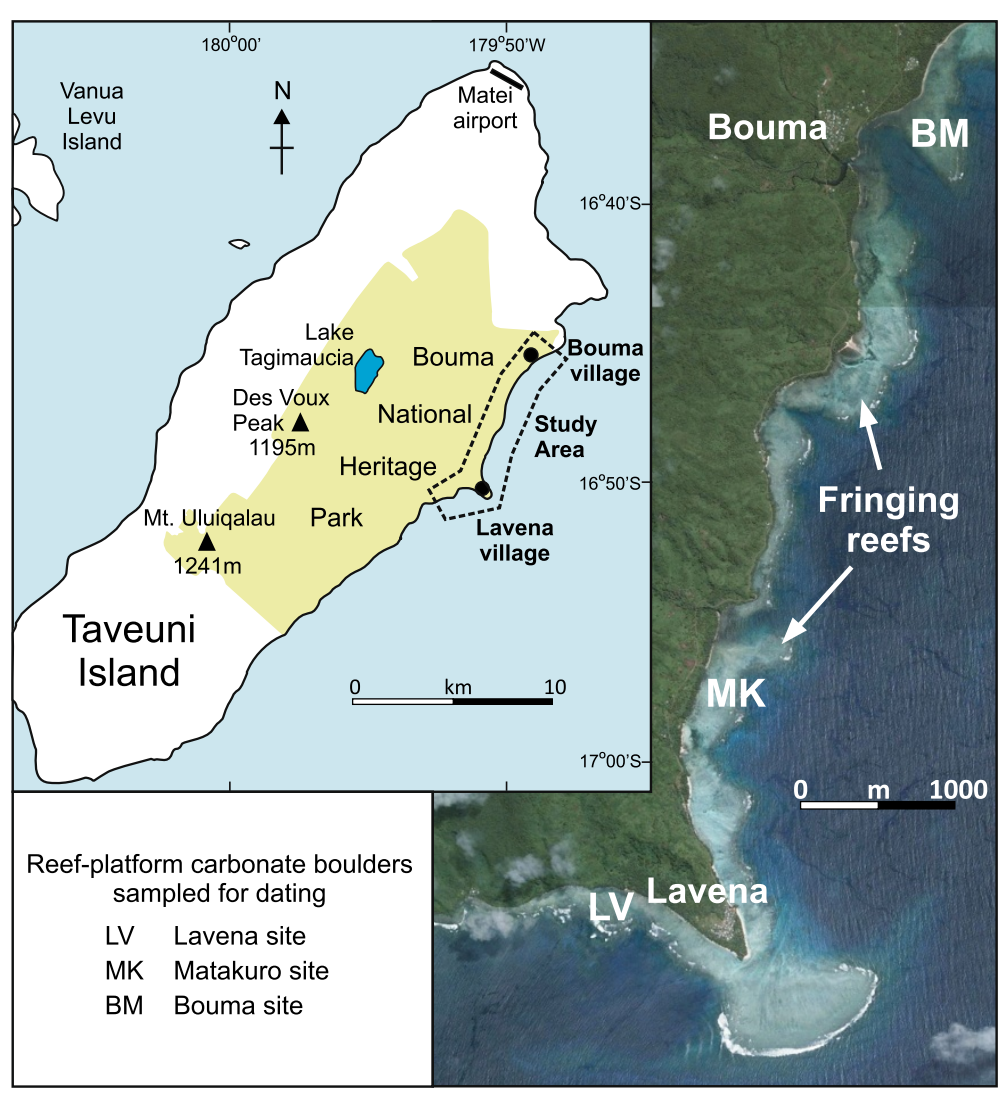

Figure 2 Taveuni Island in northern Fiji, showing the location of study sites where reef-platform boulder fields exist. Much of the coral reef coastline on the central east coast in the dashed area between Bouma and Lavena villages is a Marine Protected Area. Acknowledged source for the base satellite image: Google earth, GeoEye. 


\section{Field procedures and observations}

Following these earlier findings, a programme was implemented to sample the largest pre-TC Tomas RPCPs, in an attempt to establish by U:Th dating the approximate timing of the HEMI events that were responsible for their production. Eight RPCBs were sampled in June 2012, three at Lavena, four at Bouma (Figure 3) and one at Matakuro, the latter being the largest individual boulder observed in the study area (Table 1).

During the sampling procedure boulder surfaces infested with marine organisms were avoided, so that modern organic material was not accidentally mixed with the carbonate rock samples. Importantly for dating purposes, the youngest part of each RPCB should preferably be sampled. In several of the large Taveuni boulders, it was possible to recognise the growth direction of fossil corals, thus allowing boulder orientation to be determined. For clasts that had experienced heavy erosion, this proved much more difficult. In response, the decision was made to sample both the top and bottom surfaces of all selected RPCBs. The principal objective here was to discern the magnitude of the differences (if any) in apparent boulder age, as yielded by pairs of samples taken from opposite sides of individual boulders. Back in the laboratory, dried rock samples were measured for weight and density, before being delivered to the Radiogenic Isotope Facility at the University of Queensland in Australia for U:Th dating.

\section{Results}

From the results presented in Table 1 it is seen that the RPCBs sampled from the fringing reefs on Taveuni Island's eastern coastline have yielded a series of dates with a high level of precision (1-7 years). If we are willing to accept that the youngest of each pair of dates obtained for individual RPCBs indicates the approximate timing of the HEMI events that produced the boulders, then it is helpful to plot the data on a timeline in order to visualise the relative frequency and magnitude of the events (Figure 4). Several key observations may be highlighted. First, the recent event recorded as 1988 (sample MK1) was probably TC Raja in early 1987, which attained hurricane strength and caused widespread damage across northern Fiji, including Taveuni where the eye passed within $10 \mathrm{~km}$ of the NE coast. Second, the two boulders giving very close ages, dated as 1836 (sample BM3) and 1842 (sample LV2), can be assumed to be signatures of the same event. Third, a cluster of very powerful events is notable in the late $1600 \mathrm{~s}$ and early 1700s, which has not been repeated (or have not
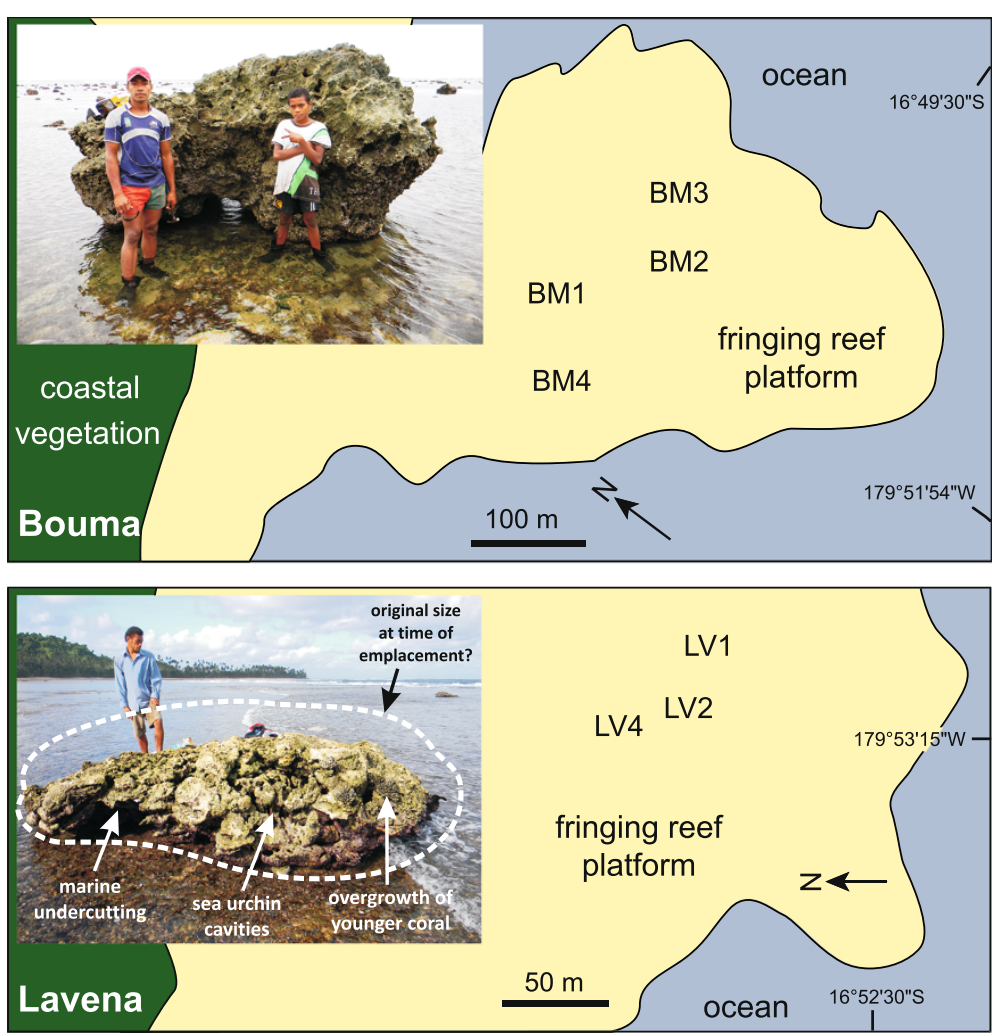

Figure 3 Location of large pre-existing RPCBs sampled for dating that predate the $\mathbf{2 0 1 0}$ TC Tomas event. The inset photos show BM1 and LV2. In LV2, fossil corals in the boulder fabric reveal that it has been overturned and now rests in an inverted position, although several colonies of Acropora coral (now dead) grew at some time post-deposition on the current upper surface of the boulder and remain in their growth orientation. Bioerosion and marine abrasion act on the boulder at unknown rates, so as to decrease its total mass and size over time. (Photos by J. Terry, June 2012). 
Table 1 Characteristics of reef-platform carbonate boulders sampled for U:Th dating

\begin{tabular}{|c|c|c|c|c|c|c|c|c|c|c|c|}
\hline Sample code & Place & Location & Orientation & $\begin{array}{l}\text { Axis dimensions } \\
\quad \mathrm{a} \times \mathrm{b} \times \mathrm{c}(\mathrm{m})\end{array}$ & $\begin{array}{c}\text { Approx. } \\
\text { volume }^{1}\left(\mathrm{~m}^{3}\right)\end{array}$ & $\begin{array}{c}\text { Approx. } \\
\text { weight (tonnes) }\end{array}$ & $\begin{array}{l}\text { Minimum flow } \\
\text { velocity for } \\
\text { transport }^{2}(\mathrm{~m} / \mathrm{s})\end{array}$ & $\begin{array}{c}\text { Sample } \\
\text { for dating }\end{array}$ & $\begin{array}{l}\text { Corrected age } \\
\text { (years AD) }\end{array}$ & $\pm 2 \sigma$ (years) & $\begin{array}{c}\text { Difference in } \\
\text { age, top to } \\
\text { base (years) }\end{array}$ \\
\hline \multirow[t]{2}{*}{ LV1 } & Lavena & $\mathrm{S} 16^{\circ} 52.395^{\prime}$ & Inverted & $4.2 \times 4.0 \times 1.3$ & 21.8 & 30.6 & $>5.1$ & top & 1513 & 7 & 157.3 \\
\hline & & W179 $53.238^{\prime}$ & & & & & & base & 1670 & 3 & \\
\hline \multirow[t]{2}{*}{ LV2 } & Lavena & $\mathrm{S} 16^{\circ} 52.392^{\prime}$ & Inverted & $4.0 \times 2.9 \times 1.0$ & 11.6 & 16.2 & $>3.7$ & top & 1793 & 3 & 49.4 \\
\hline & & $W 179^{\circ} 53.251^{\prime}$ & & & & & & base & 1842 & 2 & \\
\hline \multirow[t]{2}{*}{ LV4 } & Lavena & $\mathrm{S} 16^{\circ} 52.382^{\prime}$ & Right way & $3.9 \times 3.0 \times 1.0$ & 11.7 & 16.4 & $>2.7$ & top & 1907 & 1 & 45.6 \\
\hline & & W17953.253' & up & & & & & base & 1861 & 2 & \\
\hline \multirow[t]{2}{*}{ BM1 } & Bouma & $\mathrm{S} 16^{\circ} 49.421^{\prime}$ & Inverted & $3.9 \times 2.8 \times 2.1$ & 22.9 & 32.10 & $>5.1$ & top & 1659 & 7 & 47.7 \\
\hline & & $W 179^{\circ} 51.937^{\prime}$ & & & & & & base & 1707 & 3 & \\
\hline \multirow[t]{2}{*}{$\mathrm{BM} 2$} & Bouma & $\mathrm{S} 16^{\circ} 49.449^{\prime}$ & Right way & $3.3 \times 2.3 \times 1.9$ & 14.4 & 20.2 & $>4.3$ & top & 1763 & 3 & 24.5 \\
\hline & & W17951.906' & up & & & & & base & 1739 & 2 & \\
\hline \multirow[t]{2}{*}{$\mathrm{BM} 3$} & Bouma & $\mathrm{S} 16^{\circ} 49.438^{\prime}$ & Inverted & $3.0 \times 2.4 \times 1.6$ & 11.6 & 16.1 & $>3.6$ & top & 1809 & 3 & 27.1 \\
\hline & & W179 $51.882^{\prime}$ & & & & & & base & 1836 & 3 & \\
\hline \multirow[t]{2}{*}{ BM4 } & Bouma & $\mathrm{S} 16^{\circ} 49.443^{\prime}$ & Right way & $2.9 \times 2.4 \times 1.1$ & 7.7 & 10.7 & $>4.4$ & top & 1690 & 3 & 47.1 \\
\hline & & W179 $51.969^{\prime}$ & up & & & & & base & 1643 & 6 & \\
\hline \multirow[t]{2}{*}{ MK1 } & Matakuro & $\mathrm{S} 16^{\circ} 51.560^{\prime}$ & Inverted & $4.7 \times 3.2 \times 2.7$ & 40.6 & 56.9 & $>3.8$ & top & 1737 & 2 & 250.9 \\
\hline & & $W 179^{\circ} 52.731^{\prime}$ & & & & & & base & 1988 & 1 & \\
\hline
\end{tabular}

${ }^{1}$ Based on the rectangular, blocky boulder shapes commonly observed on Taveuni (see also [25]).

${ }^{2}$ The flow velocities $(\mathrm{m} / \mathrm{s})$ given are the minimum flows needed to set the boulders in motion as inferred from the hydrodynamic transport equations of Nandasena et al. [26]. From the growth direction of fossil corals it was possible to establish that the majority of boulders rest in an inverted position, thus the minimum flow velocity for transport by rolling (overturning) is given; it is likewise assumed that transport by rolling also occurred for those boulders now in an upright positon.

These are the largest boulders observed within the boulder fields on fringing reefs in the study area. Refer to Figure 3 for the location of the boulders. 


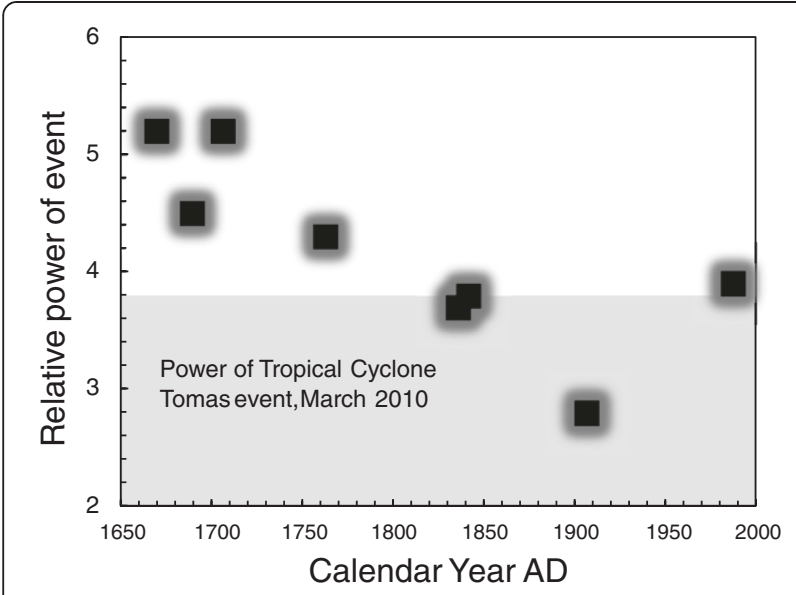

Figure 4 Timing of major HEMI events (plotted as black squares) on the eastern coast of Taveuni Island, Fiji, based on U:Th dates obtained from the largest RPCBs observed on the fringing reefs.

The relative power of the events is based on the minimum required water flow velocity for the transport of the dated boulders. Square markers are deliberately drawn large with fuzzy boundaries to represent uncertainty in both timings and magnitudes in a qualitative way. high-energy storms or tsunamis necessarily leave behind boulders or larger 'megaclasts' [27] as evidence of their occurrence. Event imprint is strongly related to the availability or not of boulders to be detached from or transported over the reef [28]. An absence of coarse clastic deposits at a particular place is therefore not proof per se of the non-occurrence of a HEMI event there.

The production of RPCBs will also be heavily influenced by the condition of adjacent coral reefs. Clearly, where fringing reefs are poorly developed, the quarrying of new clasts during HEMI events will be limited. Coral diseases on the other hand may enhance sediment availability [29]. If the time interval between successive geomorphic disturbances is less than the time required for coral reefs to recover, then less clastic material may be produced [30]. Elsewhere, deliberate human interference may be important: on fringing reefs near Nha Trang in Vietnam, the scarcity of coral boulders has been attributed to local cement factories "harvesting" them as a convenient source of limestone. Another reason for boulder collection is for use as rock armour in shoreline revetments.

left boulder deposits) in the intervening centuries. Fourth, overall it appears that at least 7 other HEMI events with similar or greater wave energy characteristics than TC Tomas in 2010 (a category-4 intensity cyclone) have occurred over the last c.350 years. By including TC Tomas, a return period of 40-45 years is established for major HEMI events since $1650 \mathrm{AD}$. This figure probably represents the maximum return period, because although the biggest RPCBs were chosen for sampling, the prohibitively high costs of U:Th dating meant that many other large boulders on Taveuni's reefs had to be ignored (see also Undetectable events section).

Perhaps the most important finding is that considerably different dates are yielded by coral samples that are sourced from the top and bottom (i.e. opposite sides) of individual RPCBs. Most age ranges span at least several decades (20-50 years). For the largest boulder (MK1), the age range spans two and a half centuries (250 years), which might not be surprising considering its size (nearly $5 \times 3 \times 3 \mathrm{~m}$ ). Although produced in the late 1980s, the mortality of the oldest corals within the fabric of this boulder occurred much earlier, during the early to mid-1700s. This example underscores one of the potential dangers of interpreting the time of a HEMI event from RPCB age-dating, especially with the most sizeable clasts (see below).

\section{Discussion}

\section{Undetectable events}

In attempting to establish the timing or frequency of unrecorded prehistorical marine inundation events on coastlines, it is important to appreciate that not all

\section{Multiple reef sources}

Further complications with timing ancient HEMI events from the ages of RPCBs may arise in situations where boulders were not quarried from living corals on the reef crest but other sources, of which several exist. Figure 1 illustrates the alternatives. Where Holocene elevated sea levels allowed coral reefs to grow upwards, remnants of these former surfaces may now exist as coral pinnacles or rochers champignons (mushroom rocks) sticking up above modern reefs. If Holocene-age mushroom rocks are undercut and toppled to become boulders on the modern reef platform, they quickly take on the appearance of true RPCBs, but their fossil corals will provide misleading dates and therefore confound coastal hazard interpretation. Although this is not the case at the Taveuni study site, a similar scenario might be envisaged for RPCBs excavated from older parts of the reef structure, such as offshore reef slopes, or if dredged from accumulations of preexisting fore-reef talus. This occurred at Cape Pakarang in Thailand during the 2004 Indian Ocean Tsunami [31]. In such scenarios, the ages of coral mortality are unrepresentative of (i.e. older than) the HEMI events that transported the RPCBs onto the reef platform because coral mortality occurred an unknown time earlier. Boulder ages then provide only a maximum limit for the age of the event in question [19].

\section{Ancient storms or tsunamis on Taveuni?}

Whether the ancient HEMI events recorded on Taveuni were caused by high-intensity storms or tsunamis remains unknown. Distinguishing between storm and tsunami boulders directly from their physical characteristics 
persists as a contentious issue (e.g. [11,28,32-34]). But given the fact that Fiji lies in the cyclone belt of the SW Pacific [35], it is reasonable to infer that several were cyclone-driven events. Might the cluster around 1700 AD therefore signify a multi-decadal phase of increased highintensity storm activity? This remains to be investigated. The possibility of palaeotsunamis as an alternative origin must also not be ruled out, as demonstrated by the devastating impacts of the earthquake-generated 2009 tsunami on nearby Samoa [36]. However, following the multiproxy census by Goff et al. [37], no major tsunami events were reported or recorded around $1700 \mathrm{AD}$ in the South Pacific region, so we favour the storm hypothesis. In this case, how well the $40-45$ year return period for major HEMI events on Taveuni represents the wider regional picture also deserves consideration. Since TCs are on average more (less) frequent farther west (east) in the tropical SW Pacific, the given return period may be an underestimate (overestimate) for islands elsewhere in the region, although identifying any spatial patterns clearly needs much deeper analysis.

\section{Conclusions}

The timing and frequency of HEMI events through the Holocene has been achieved for tropical coastlines in Queensland, Australia [38,39], the Netherlands Antilles in the Caribbean [9] and for islands in the South China Sea $[19,40]$. In the Taveuni situation in Fiji, conservation of the Marine Protected Area along the BoumaLavena coastline is a matter of priority. Information on the timing and frequency of prehistorical HEMI events is therefore useful in assessing the future risks of coastal hazards. RPCB samples have yielded a series of dates with a high level of precision (1-7 years), giving an estimated return period for major inundation events of 40-45 years since 1650 AD. This seems reasonable according to regional TC records since the start of the satellite era [41].

It is not surprising that considerably different dates are yielded by coral samples sourced from the top and bottom (i.e. opposite faces) of individual RPCBs. Yet such a finding provides valuable insight on how a paired sampling strategy is necessary for large boulders, in order to achieve more meaningful dating and interpretation. Other considerations are that effort should be directed to identifying boulder sources and that sampling should concentrate on those boulders with a known origin. Nonetheless, it is unavoidable that post-depositional evolution of RPCBs may involve multiple reworking by successive events and the effects of bioerosion and weathering, which alter the integrity of boulder fabric. These processes have the potential to gradually clear the reef flat of older boulder deposits and eventually erase the imprint of some past marine inundation events. Reconstruction of HEMI events from reefplatform carbonate boulders alone might be incomplete in consequence and a multi-proxy approach should therefore be adopted wherever possible.

\section{Abbreviations \\ HEMI: High-energy marine inundation; RPCB: Reef-platform carbonate boulder; TC: Tropical cyclone.}

\section{Competing interests}

The authors declare that they have no competing interests.

\section{Authors' contributions}

JPT organized and participated in two field expeditions, interpreted data and drafted the manuscript. SE participated in one field expedition, assisted with data interpretation and manuscript preparation. Both authors read and approved the final manuscript.

\section{Acknowledgements}

The authors received much assistance in the field from Messrs. losefo Soroalau, Tevita Mafi and Iliesa Qoli, for which they extend their appreciation. The chiefs and elders of Bouma and Lavena villages are thanked for allowing access to their coastlines during fieldwork. J. Terry acknowledges financial support from the National University of Singapore through the Singapore Ministry of Education research grant no. FY-2012-FRC2-005. Dating of samples was supervised by Dr Y. Feng at the Radioisotope Facility at the University of Queensland, Brisbane. The authors are grateful to four anonymous reviewers who provided constructive comments on the original manuscript.

\section{Author details}

${ }^{1}$ College of Sustainability Sciences and Humanities, Zayed University, Dubai, United Arab Emirates. ${ }^{2}$ Laboratoire de Géomorphologie et Environnement Littoral, École Pratique des Hautes Études, CNRS UMR Prodig, Dinard, France. ${ }^{3}$ Laboratoire d'excellence CORAIL, École Pratique des Hautes Études, CRIOBE, Papeete, Moorea, Polynésie française.

Received: 10 February 2014 Accepted: 4 September 2014 Published online: 27 September 2014

\section{References}

1. Goff J (2013) Preface. In: Terry JP, Lau, AYA, Etienne S, Reef-Platform Coral Boulders: Evidence for High-Energy Marine Inundation Events on Tropical Coastlines. Springer, Heidelberg, http://dx.doi.org/10.1007/978-981-4451-33-8

2. Switzer AD, Yu F, Gouramanis C, Soria JLA, Pham DT (2014) Integrating different records to assess coastal hazards at multi-century timescales. J Coast Res SI 70:723-728

3. Buckley ML, Wei Y, Jaffe BE, Watt SG (2012) Inverse modeling of velocities and inferred cause of overwash that emplaced inland fields of boulders at Anegada, British Virgin Islands. Nat Hazards 63:133-149, doi:10.1007/s11069011-9725-8

4. Etienne S, Buckley M, Paris R, Nandasena AK, Clark K, Chagué-Goff C, Goff J, Richmond B (2011) The use of boulders for characterizing past tsunamis: lessons from the 2004 Indian Ocean and 2009 South Pacific tsunamis. Earth-Sci Rev 107:75-90, doi:10.1016/j.earscirev.2010.12.006

5. Frohlich C, Hornbach MJ, Taylor FW, Shen CC, Moala A, Morton AE, Kruger JAF (2009) Huge erratic boulders in Tonga deposited by a prehistoric tsunami. Geol 37:131-134, doi:10.1130/G25277A.1

6. Paris R, Wassmer P, Sartohadi J, Lavigne F, Barthomeuf B, Desgages É, Grancher D, Baumert P, Vautier F, Brunstein D, Gomez C (2009) Tsunamis as geomorphic crisis: lessons from the December 26, 2004 tsunami in Lhok Nga, west Banda Aceh (Sumatra, Indonesia). Geom 104:59-72, doi:10.1016/ j.geomorph.2008.05.040

7. Chen B, Chen Z, Stephenson W, Finlayson B (2011) Morphodynamics of a boulder beach, Putuo Island, SE China coast: the role of storms and typhoon. Mar Geol 283:106-115, doi:10.1016/j.margeo.2010.10.004

8. Goto K, Miyagi K, Kawana T, Takahashi J, Imamura F (2011) Emplacement and movement of boulders by known storm waves - Field evidence from the Okinawa Islands, Japan. Mar Geol 283:66-78, doi:10.1016/j. margeo.2010.09.007 
9. Scheffers AM, Engel M, May SM, Scheffers SR, Joannes-Boyau R, Hänssler E, Kenendy K, Kelletat DH, Brückner H, Vött A, Schellmann G, Schäbitz F, Radtke U, Sommer B, Willershäuser T, Felis T (2013) Potential and limits of combining studies of coarse- and fine-grained sediments for the coastal event history of a Caribbean carbonate environment. Geol Soc London Spec Publ 388, doi:10.1144/SP388.4

10. Suanez S, Fichaut B, Magne R (2009) Cliff-top storm deposits on Banneg Island, Brittany, France: Effects of giant waves in the Eastern Atlantic Ocean. Sed Geol 220:12-28

11. Goto K, Miyagi K, Kawamata H, Imamura F (2010) Discrimination of boulders deposited by tsunamis and storm waves at Ishigaki Island, Japan. Mar Geol 269:34-45, doi:10.1016/j.margeo.2009.12.004

12. Noormets R, Felton EA, Crook KAW (2002) Sedimentology of rocky shorelines: 2. Shoreline megaclasts on the north shore of Oahu, Hawaiiorigins and history. Sed Geol 150:31-45, doi:10.1016/S0037-0738(01)00266-4

13. Shah-hosseini M, Morhange C, Beni AN, Marriner N, Lahijani H, Hamzeh M, Sabatier F (2011) Coastal boulders as evidence for high-energy waves on the Iranian coast of Makran. Mar Geol 290:17-28, doi:10.1016/j. margeo.2011.10.003

14. Engel M, May SM (2012) Bonaire's boulder fields revisited: evidence for Holocene tsunami impact on the Leeward Antilles. Quat Sci Rev 54:126-141, doi:10.1016/j.quascirev.2011.12.011

15. Paris R, Fournier J, Poizot E, Etienne S, Morin J, Lavigne F, Wassmer P (2010) Boulder and fine sediment transport and deposition by the 2004 tsunami in Lhok Nga (western Banda Aceh, Sumatra, Indonesia): a coupled offshoreonshore model. Mar Geol 268:43-54, doi:10.1016/j.margeo.2009.10.011

16. Terry JP, Lau AYA, Etienne S (2013) Reef-Platform Coral Boulders: Evidence for High-Energy Marine Inundation Events on Tropical Coastlines. Springer, Heidelberg, doi:10.1007/978-981-4451-33-8

17. Goff JR, Terry JP (2012) Living with natural hazards in the Asia-Pacific region. In: Terry JP, Goff JR (eds) Natural hazards in the Asia-Pacific region: recent advances and emerging concepts, vol 361. Spec Publ, Geol Soc London, pp 1-2, doi:10.1144/SP361.1

18. Goto K, Okada K, Imamura F (2009) Characteristics and hydrodynamics of boulders transported by storm waves at Kudaka Island, Japan. Mar Geol 262:14-24, doi:10.1016/.jmargeo.2009.03.001

19. Yu K, Zhao J, Shi Q, Meng Q (2009) Reconstruction of storm/tsunami records over the last 4000 years using transported coral blocks and lagoon sediments in the southern South China Sea. Quat Intern 195:128-137, doi:10.1016/j.quaint.2008.05.004

20. Araoka D, Inoue M, Suzuki A, Yokoyama Y, Edwards RL, Cheng H, Matsuzaki H, Kan H, Shikazono N, Kawahata H (2010) Historic 1771 Meiwa tsunami confirmed by high-resolution U/Th dating of massive Porites coral boulders at Ishigaki Island in the Ryukyus, Japan. Geochem Geophys Geosyst 11: Q06014, doi:10.1029/2009GC002893

21. Zhao J, Neil DT, Feng Y, Yu K, Pandolfi JM (2009) High-precision U-series dating of very young cyclone-transported coral reef blocks from Heron and Wistari reefs, southern Great Barrier Reef, Australia. Quat Intern 195:122-127, doi:10.1016/.quaint.2008.06.004

22. Emiliani C (1992) Planet Earth: Cosmology, Geology, and the Evolution of Life and Environment. Cambridge University Press, Cambridge

23. Cobb KM, Charles CD, Cheng H, Kastner M, Edwards RL (2003) U/Th-dating living and young fossil corals from the central tropical Pacific. Earth Planet Sci Lett 210:91-103, doi:10.1007/s11069-011-9725-8

24. Etienne S, Terry JP (2012) Coral blocks, gravel tongues and sand sheets: features of coastal accretion and sediment nourishment by Cyclone Tomas (March 2010) on Taveuni Island, Fiji. Geom 175-176:54-65, doi:10.1016/j. geomorph.2012.06.018

25. Gienko GA, Terry JP (2013) Three-dimensional modeling of coastal boulders using multi-view image measurements. Earth Surf Proc Landf 39:853-864, doi:10.1002/esp.3485

26. Nandasena NAK, Paris R, Tanaka N (2011) Reassessment of hydrodynamic equations to initiate boulder transport by high energy events (storms, tsunamis). Mar Geol 281:70-84, doi:10.1016/.jmargeo.2011.02.005

27. Terry JP, Goff J (2014) Megaclasts: proposed revised nomenclature at the coarse end of the Udden-Wentworth grain-size scale for sedimentary particles. J Sed Res 84:192-197, doi:10.2110/jsr.2014.19

28. Switzer AD, Burston JM (2010) Competing mechanisms for boulder deposition on the southeast Australian coast. Geom 114:42-54, doi:10.1016/ j.geomorph.2009.02.009
29. Spiske M, Jaffe BE (2009) Sedimentology and hydrodynamic implications of a coarse-grained hurricane sequence in a carbonate reef setting. Geol 37:839-842, doi:10.1130/G30173A.1

30. Harmelin-Vivien ML (1994) The effects of storms and cyclones on coral reefs: a review. J Coast Res SI 12:221-231

31. Goto K, Chavanich SA, Imamura F, Kunthasap P, Matsui T, Minoura K, Sugawara D, Yanagisawa H (2007) Distribution, origin and transport process of boulders deposited by the 2004 Indian Ocean tsunami at Pakarang Cape, Thailand. Sed Geol 202:821-837, doi:10.1016/j.sedgeo.2007.09.004

32. Benner R, Browne T, Brückner H, Kelletat D, Scheffers A (2010) Boulder transport by waves: progress in physical modelling. Zeit Geom NF Supp 54 (3):127-146

33. Lorang MS (2011) A wave-competence approach to distinguish between boulder and megaclast deposits due to storm waves versus tsunamis. Mar Geol 283:90-97, doi:10.1016/.jmargeo.2010.10.005

34. Pignatelli C, Sansò P, Mastronuzzi G (2009) Evaluation of tsunami flooding using geomorphologic evidence. Mar Geol 260:6-18, doi:10.1016/j. margeo.2009.01.002

35. Terry JP, Gienko G (2010) Climatological aspects of South Pacific tropical cyclones, based on analysis of the RSMC-Nadi (Fiji) regional archive. Clim Res 42:223-233, doi:10.3354/cr00912

36. Richmond BM, Buckley M, Etienne S, Chagué-Goff C, Clark K, Goff J, Dominey-Howes D, Strotz L (2011) Deposits, flow characteristics, and landscape change resulting from the September 2009 South Pacific tsunami in the Samoan islands. Earth-Sci Rev 107:38-51, doi:10.1016/j. earscirev.2011.03.008

37. Goff J, Chagué-Goff C, Dominey-Howes D, MCAdoo B, Cronin S, Bonté-Grapetin M, Nichol S, Horrocks M, Cisternas M, Lamarche G, Pelletier B, Jaffe B, Dudley W (2011) Palaeotsunamis in the Pacific Islands. Earth-Sci Rev 107:141-146

38. Hayne M, Chappell J (2001) Cyclone frequency during the last 5000 years at Curacoa Island, north Queensland, Australia. Palaeogeo Palaeoclim Palaeoecol 168:207-219, doi:10.1016/S0031-0182(00)00217-0

39. Yu K, Zhao J, Roff G, Lybolt M, Feng Y, Clark T, Li S (2012) High-precision U-series ages of transported coral blocks on Heron Reef (southern Great Barrier Reef) and storm activity during the past century. Palaeogeo Palaeoclim Palaeoecol 337-338:23-36, doi:10.1016/.jpalaeo.2012.03.023

40. Yu K, Zhao J, Collerson KD, Shi Q, Chen T, Wang P, Liu T (2004) Storm cycles in the last millennium recorded in Yongshu Reef, southern South China Sea. Palaeogeo Palaeoclim Palaeoecol 210:89-100, doi:10.1016/j. palaeo.2004.04.002

41. Terry JP (2007) Tropical Cyclones: Climatology and Impacts in the South Pacific. Springer, New York, 210pp

doi:10.1186/s40562-014-0014-8

Cite this article as: Terry and Etienne: Potential for timing high-energy marine inundation events in the recent geological past through age-dating of reef boulders in Fiji. Geoscience Letters 2014 1:14.

\section{Submit your manuscript to a SpringerOpen ${ }^{\circ}$ journal and benefit from:}

- Convenient online submission

- Rigorous peer review

- Immediate publication on acceptance

- Open access: articles freely available online

High visibility within the field

- Retaining the copyright to your article

Submit your next manuscript at $>$ springeropen.com 